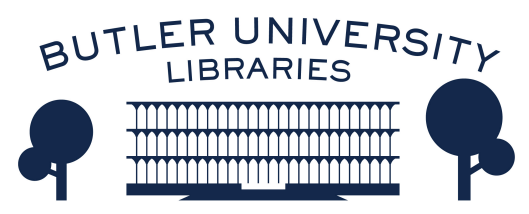

Journal of Hindu-Christian Studies

March 2013

\title{
Sacred Land, Common Ground, Contested Territory: the Healing Mother of Velankanni Basilica and the Infant Jesus Shrine in Bangalore
}

Vasudha Narayanan

Follow this and additional works at: https://digitalcommons.butler.edu/jhcs

Part of the Religion Commons

\section{Recommended Citation}

Narayanan, Vasudha (2004) "Sacred Land, Common Ground, Contested Territory: the Healing Mother of Velankanni Basilica and the Infant Jesus Shrine in Bangalore," Journal of Hindu-Christian Studies: Vol. 17, Article 25.

Available at: https://doi.org/10.7825/2164-6279.1535

The Journal of Hindu-Christian Studies is a publication of the Society for Hindu-Christian Studies. The digital version is made available by Digital Commons @ Butler University. For questions about the Journal or the Society, please contact cbauman@butler.edu. For more information about Digital Commons @ Butler University, please contact digitalscholarship@butler.edu. 


\title{
Sacred Land, Common Ground, Contested Territory: the Healing Mother of Velankanni Basilica and the Infant Jesus Shrine in Bangalore
}

\author{
Vasudha Narayanan \\ University of Florida
}

\author{
Nenjil aadum deivame \\ en ninavai aalum deivame \\ manatil koyil ceykinren \\ makilnutu unnai alaikkinren \\ $\mathrm{O}$ deity (deivam) who dances in my \\ heart \\ $O$ deity who rules my mind \\ I will make a temple in my heart \\ (mind) \\ With joy, I will invite you...
}

$$
\text { --Popular Song }
$$

THE local tea stall blares the Tamil song as I walk in a street near the shrine of the Infant Jesus in Bangalore, in the state of Karnataka. The tune and words sound like any number of Tamil film songs I have heard. And, in fact, I do think it is a film song for it is not unusual in this genre of romantic music to refer to one's lover in a hyperbolic way as a metaphoric god or goddess. But these words are followed by the name that tells me it is not film musicCome, $\mathrm{O}$ lord, and reside with happiness in my heart, Come O Yesu....

It is a song addressed to the baby Jesus, and, as I find out later, from a popular cassette "Wondrous child, Yesu." The words of the next song seem even more familiar-very pious, but sharing in the common idiom of Tamil piety rather than having a uniquely identifiable Christian tone to it:
tiru talam vanden
un malar padam tola vanden
I came to the sacred place
I came to worship the flower feet

Vasudha Narayanan is Professor of Religion and has been teaching at the University of Florida since 1982. She is a past President of the American Academy of Religion and the Society for Hindu-Christian Studies. She was educated at the Universities of Madras and Bombay in India, and Harvard University. Her fields of interest are the Sri Vaishnava tradition; Hindu traditions in India, Cambodia, America; Hinduism and the environment; and gender issues. She is currently working on Angkor Wat and other Hindu temples in Cambodia with a fellowship from the American Council of Learned Societies. Her latest book is Understanding Hinduism (Oxford, 2004). Recent articles include: "Vaisnava Traditions in Cambodia: 5-12th centuries." Festschrift for Professor Dennis Hudson. Journal of Vaisnava Studies. Fall 2002, "Religious Biography and Regional Identity" in Indian Islamic Traditions, edited by Richard Eaton. (New Delhi: Oxford); "Hinduism: (Her Spaces)" in Her Voice, Her Faith, edited by Arvind Sharma and Katherine K. Young (Westview Press, 2003); "Gender in a Devotional Universe" in The Blackwell Companion to Hinduism, edited by Gavin Flood (Blackwell, 2003) and "Embodied Cosmologies: Sights of Piety, Sites of Power" Presidential Address. Journal of the American Academy of Religion, 71/3, Fall 2003. 
The Tamil songs, I heard later, have been composed specifically for the Infant Jesus who is enshrined and worshiped in Bangalore. Sacred places and flower feet are standard tropes in Tamil poetry; every other set of poems in the works of the Vaishnava and Saiva saints who lived towards the end of the first millenium $\mathrm{CE}$ is filled with the glory of a sacred place and the flower feet of the deity.

I had heard similar songs near the Basilica of Our Lady of Health in Velankanni, in the neighboring state of Tamilnadu. Velankanni is about eight miles from Nagapattinam and the site of a Marian appearance. Here, Mary is worshiped as Arogya Mata, the Mother of Health. Velankanni is a Christian site; Nagapattinam nearby has several Hindu temples; and a few miles down the road is Nagore, the home of a famous Muslim dargah, where the body of Sufi saint, Shahul Hamid (15 $5^{\text {th }}$ century) is enshrined. Similar tea shops, similar music, similar, and sometimes, the same Hindu pilgrims. In Nagapattinam, there were Hindu devotees; in Nagore, Hindu and Muslim; in Velankanni, Hindu, Christian, and perhaps others I could not distinguish. There seemed to be a similar crowd here in Bangalorelargely south Indian, many of them Tamil or Kannada-speaking Hindus. I feel like I am in the set of an Indian movie, a blockbuster like "Amar, Akbar, and Anthony" which, as one can hazard a guess, speaks of communal/religious integration in India.

There have been many classical theological studies comparing Hindu and Christian thought in India, but it is only recently that rich studies on "popular religion" are coming out. In this essay, I will explore one facet of "lived religion" for some Hindus and Christians in Tamilnadu and Karnataka- the "on the ground" relationship between Hindus and Christians. This is literally on the ground, on the sacred ground of Velankanni and Viveknagar, Bangalore.

"Lived Religion" is an important lens for the study of religion in the Americas in recent years (Hall, Orsi 1997). Hall observes that historians of religion in America say that "while we know a great deal about the history of theology and (say) church and state, we know next-to-nothing about religion as practiced and precious little about the everyday thinking and doing of lay men and women." (Hall 1997: vii) While there are any number of studies which look at the history of theology, or the institutional stances and positioning, the category of "lived religion" has only now come into its own in the study of religion in America.

The category of "lived religion" bridges the commonly perceived divisions of "high" and "popular" religions. The term "popular religion," much used by historians of the Reformation, came to refer to those practices that emerged between the official, institutionalized Christianity (also called "elite" or "learned") and profane or "pagan" culture. It was in these spaces that human beings had autonomy and agency and transformed practices to fit in with local cultures. "Lived religion" eschews the elite/ popular, institutional/ lay, high/low dichotomies.

There is yet another pair of categories, not quite a dichotomy that "lived religion" cuts through in this essay. These are the categories of "ethnic" and "religious." Christians in Tamilnadu are proud of their ethnic culture, their Tamil heritage. There is no neat divide between "Christian" and "Tamil." On-the-ground religion does not, in fact, fit neatly into these dichotomies or categories. In many cases priests, institutions, and lay people come together in perpetuating ideas or practices which some scholars call "popular." In other words, it is not the case that the priests and clergy do "high" religion and that this is opposed to the practices of the common people. The devotional exercises seen at Velankanni and the Shrine of the Infant Jesus in South India are part of every day life to millions of Hindus and Christians, men and women, clergy, priests, and lay people. 
The category of lived religion also illumines and nuances what we can say about the relationship between Hindus and Christians in South India. As can be expected, one cannot make generalizations on the relationship-any description or analysis would depend on the historical, ritual, and social contexts. Historically, while Hindus associated Christianity with hospitals and education, this may be less true in the post-colonial era. Ritually, while Hindus may enthusiastically participate in certain rites which they think of as "ethnic" in some Christian places of worship, and for specific reasons, they certainly do not participate in many other practices and do not frequent all churches. In the social context, while Hindus may have a cordial relationship with the Christian management of a parochial school, where they have waited in line for several years to get admission for their children's education, or have very good Christian friends, they may get very angry at some of the conversion rhetoric and strategies exercised by Christian missionaries.

In discussing "lived religion," I will focus on two churches well known in South India: the Basilica of Our Lady of Health at Velankanni, Tamilnadu, and the Infant Jesus Shrine at Viveknagar, Bangalore. These are two of the most popular shrines among Christian places of worship for Hindu devotees. The forms of the deities venerated here are at once familiar to Hindus- the Healing Mother at Velankanni, and the baby Jesus in the Bangalore shrine. Hindus worship the deity through many relationships-father, mother, lover, child, warrior-protector, etc. Perhaps the most beloved representations in south India are the Mother and Child images-and it is these that we see in Velankanni and in Bangalore. In Bangalore Jesus is not the Jesus on the Cross or the risen Christ; it is the everbeloved baby Jesus, spoken of in terms that are common when addressing the baby Krishna or the child Murugan in Tamilnadu.

\section{Velankanni}

Located about nine miles south of Nagapattinam and about 150 miles south of Chennai (Madras) in the state of Tamilnadu, Velankanni (also spelled Velanganni and Vailankanni) is a popular tourist destination for Hindus. In fact, an internet search for this name will bring up dozens of tour operators who have included this Basilica as part of a package vacation. While there are hundreds of pilgrims through the year, the crowds especially swell during the feast days for the Virgin Mary between late August and early September.

The received narratives recounted in popular books sold near the shrines (Samy, Gabriel, Irudayam, and Pankiras) as well as internet sites, speak of how it all came to be. Three miracles are associated with this holy place. The first narrative, located c. 1560 , speaks of a young boy who was sleeping near a pond in Velankanni. Near him was a container of milk which he was carrying to his master. Suddenly, he saw a beautiful woman carrying a baby; mother and child were engulfed in effulgence. The mother asked him for some milk which he gave with happiness. He proceeded to his destination and explained to his master why the quantity of milk was less than expected. However, when he opened the container, the milk began to increase, and the pitcher became full. Master and servant ran to the place where the apparition had occurred and venerated the spot near the tank. Eventually they built a little chapel there, and the pond where May appeared was called Mata Kulam or Mother's pond.

The second story speaks of the Virgin Mary appearing to a lame boy who was selling buttermilk near the same pond and curing him. This is said to have been at the end of the $16^{\text {th }}$ century. He was apparently directed to go to a wealthy Catholic man who lived nearby and ask him to build a church on the spot where she appeared. The church is supposed to have been built soon after this incident. 
The third "big" miracle is said to have happened at the end of the $17^{\text {th }}$ century when the Virgin saved Portuguese sailors from a violent storm in the Bay of Bengal. The sailors were thrown ashore in Velankanni on the $8^{\text {th }}$ of September, the feast day of the Virgin Mary. In gratitude they built a chapel, 12 feet by 24 feet with a dome. The building underwent major changes several times. In 1962 Pope John XXIII raised it to the level of a minor basilica. (Gabriel et al. 5-12) Located, like the Nagore dargah, on the sea shore, it is swept by tropical breezes and multitudes of pilgrims. And Nagore too, like Velankanni, has its own story of how the saint Shahul Hamid saved a Dutch ship and its sailors from sinking.

While these three miracles frame the narrative history of Velankanni, there are hundreds of other miracles that are attested to by devotees. People come in search of promotions, marriages, cures, success in business, and a host of other wishes, and pray to the Mother. Although there are any number of reasons as to why the pilgrims come here, the site is specially known for healing.

The special feast for Mary is held, as in many parts of the world, in late August, early September. The celebrations have a uniquely local-they are not called "Hindu"color as they do in the urs, the celebration for Shahul Hamid, down the road. The annual festivals for Shahul Hamid, Arogya Mata Mary, and the Hindu deities in Nagapattinam all begin with the raising of a ritual, sacred flag. This marks the official commencement of the festival; in Velankanni the ritual flag is raised on August 29 ; the lowering of the flag denotes the end on September $8^{\text {th }}$. An estimated 1.5 million people come to witness and participate in the festivities. Liturgies, cultural events, processions in the road, private devotions, are all part of these celebrations.

\section{The Infant Jesus Shrine, Bangalore}

Every Thursday, the Deccan Herald, the local newspaper in Bangalore has dozens of paid "thanksgiving" testimonials. These public testimonials thank the Infant Jesus of the shrine in Viveknagar, Bangalore, for fulfilling various petitions. From the names on these testimonials, and those on the shrine's website, one can discern that some are Hindu and some Christians. Since several names are common to both communities, it is not possible to know the religious identity of all the people who post such messages. The thanksgiving is offered for Jesus' help in solving a domestic or professional problem.

The Infant Jesus Shrine is relatively new to the landscape of Bangalore. Around the mid nineteen sixties a parish priest saw a rose garden and thought wistfully that it would be a good place for a church. After saying a cycle of nine novenas a day to the Infant Jesus of Prague for two months, his wish was fulfilled and the land bought for the church. In 1969 the foundation was laid and by a series of what seemed to be miracles-all of which happened on Thursdays-permission was granted for the church to be built there. Several construction projects ensued and several miracles have been reported. While there are crowds everyday, the long lines coming for "darshan"-viewing-of the Infant Jesus on Thursdays are especially long. People kneel before, bow down Hindu-style, bring garlands, or light candles for Infant Jesus and petition him. A church shop sells silver and stainless steel oil lamps, normally used for votive rituals in Hindu traditions, candles, cassette tapes, booklets etc., telling us how it all came to be.

Hindus flock -literally-to the Infant Jesus shrine regularly, or go to the Velankanni Basilica on pilgrimage. The land where these shrines stand are considered to be sacred and the votive practices similar to the ones they perform in Hindu temples or when they frequent the local dargahs where a Sufi saint is enshrined. 


\section{Inculturation, Ethnic-Tamil, or Religious-Hindu Votive practices?}

Hindus of all castes and economic classes frequent the Velankanni shrines in Nagapattinam, and in Chennai, as well as the Infant Jesus shrine in Bangalore. They light candles, say their prayers, shave their heads as an act of piety, or offer silver models of various parts of the body. The latter practice is very common in Hindu temples, Muslim dargahs, and some Christian shrines in South India. Anyone who seeks a cure or relief from illness will buy a small flat piece of silver which has an etching of that part of the body which is ailing and place it in the offering box. These etchings are sold by the many vendors nearby or by the local institutional authorities. When cured, they may return to do the same ritual again. Thus, if one suffers from persistent migraine attacks, one may buy a small flat silver (or what passes for silver) piece with a head etched on it and drop it in the donation box. Hindus call this silver piece pratima (Sanskrit for "image"); most people call it malar (Tamil for "flower"). If one has several ailments, one can cover all bases and simply buy an etching of a whole male or female body as an offering to the Mother of Healing or to the Infant Jesus.

Nor are these facsimiles limited to body organs. Among the most frequently bought etchings and models are houses, cars, and motor bikes. These are bought and offered if one either wants to successfully buy or sell a house or a car. Students and budding authors buy little carvings of pens or books for success in examinations. In the Velankanni basilica and the Nagore dargah, both of which are on the sea shore, local people frequently offer etchings of fishing boats. These metallic pieces come in varying sizes-the smallest is about one inch by half an inch, and the larger ones may be as big as six inches square. There are some slight regional variations -in Velankanni, for instance, sometimes, pilgrims may initially offer a wax candle model of a head or a torso and, when cured, offer a silver etching.

This traditional votive exercise is based on notions of simulative magic, visualization, and divine grace. By offering a metallic etching resembling the ailing organ, one is visualizing-very palpably-that part which needs healing. The cure is said to happen magically and/ or through divine grace-devotees do not make the fine distinctions that anthropologists and theologians work with. Hindus think of this as their custom and think they are worshiping a divine power in the way they know best. Christians, on the other hand, think of this as a Tamil custom, a local, ethnic custom. And the clergy are at pains to point out-in the official texts - that this is not "simony," the practice by which spiritual favors are "sold." And indeed, the custom is quite local and although not unheard of, is not well known or practiced north of Andhra Pradesh or Karnataka. The common custom in some temples and many dargahs in northern India is for Hindu pilgrims to tie a little thread around one of the steel bars, marble carvings, or pillars, with one's wish in mind. Thus, the votive ritual of presenting silver or metallic etchings is quite Tamil in its origin and is seen wherever the Tamil influence extends in Karnataka and Andhra Pradesh.

Other votive practices which are common to both Hindus and Christians, and which are local in nature, are seen in Velankanni. Pilgrims bathe in the sea-a common Hindu activity on certain days of the ritual calendar-and some shave their hair. Some Hindu pilgrims take a vow that they will roll with their bodies around temples (anga pradakshinam). This is now done at Velankanni. It is acknowledged explicitly that these are local practices:

Pilgrims from all over the country and even other countries flock to the site, bathe in the sea, have their heads shaved (the hair later being 
auctioned by the priests), and then walk on their knees or roll up to the shrine, lending a unique Indian touch to the entire ceremony. (Internet site \#2)

Bathing in the sea, shaving of the hair, and rolling to the shrine are Hindu idioms of worship. Christians also participate in some of these forms of worship but liken them to wearing a sari or sometimes to wearing a forehead mark-although Hindus may connect some of these customs' as religious, they are more in line with what we may call "civil religion" in India. By and large, Hindus bring their piety and practice with them. Though not unheard of, they seldom do typically "Catholic" rituals like the stations of the cross unless they are told that will deliver the miracle they hope for. From their lens, what we have is Christian apparition, Hindu forms of piety; Christian vision, Hindu frames; Christian ground, Hindu rituals.

\section{Sacred Land, Common Ground}

Velankanni is several centuries older than the Infant Jesus shrine. Many pilgrims consider it as hallowed ground, a sacred place (Tamil: tiru talam). The Tamil words "tiru talam" are used to speak of the Saiva or Vaishnava holy places where there is said to have been a hierophany. The language used for articulating this sacrality, therefore, is certainly very Hindu. From Puranic literature to popular songs, from patriotic literature to personal declarations of intention (sankalpa) before commencing a ritual, Hindus extol the sacred land of India, America, or wherever they are, and their town in particular. This trope of pilgrimage and sacrality of places so common in India is not popular in modern/ post-modern topographies. While the written materials do not speak about this sacrality of Velankanni or Infant Jesus, the popular songs in cassettes reaffirm the notion.

\author{
Saranam, saranam, saranam...I take \\ refuge, I take refuge... \\ I came to the sacred place \\ He [ie, Jesus] said that the child and \\ god were one \\ he spoke of the way \\ for us to become a child \\ I came to the sacred shrine \\ (sannidhi) \\ to worship the feet of the child \\ I lost myself in the babble of a child \\ I forgot myself \\ I came to the sacred place \\ I came to worship the flower feet
}

Saranam is to take refuge; it is to surrender oneself totally to someone who can protect you. Vaishnava and Saiva poets sought the deity as a refuge, and the word saranam or saranagati is used in many Hindu communities as the ultimate act of devotion. This surrender or seeking of refuge was articulated by the poets when they were in any one of the many Saiva or Vaishnava shrines (sannidhi) where the deity is enshrined. Thus, words like sannidhi, saranam, and "sacred place" (tiru talam) all push the right buttons for a Tamil-speaking audience, whether Hindu or Christian. These idioms of worship are now seen in the popular songs available in CDs or cassette tapes. Add to these words the lively beat of Tamil film music, and the messages flow all over, between and through the fuzzy boundaries of the local Hindu and Christian traditions in this specific pilgrimage context.

The most common term for pilgrimage in Sanskrit and, by extension, in Tamil, is tirtha yatra-literally, traveling to sacred places. Many Hindu pilgrims also used to walk on pilgrimage routes (pada yatra), and these terms are used to describe the pilgrimage to Velankanni. (Samy 29) It is certainly true that as is the case with many major Hindu temples, we see pilgrims walking towards the holy place from several miles away. More important, during the festival days, there are ratha yatras, or chariots pulled by devotees. Seen in many 
Hindu temples which can afford them, these are giant temple-on-wheels requiring several hundreds of devotees to pull them through the streets. The most important one in India is usually held in June in the Puri temple in Orissa, where lord Jagannatha is taken in a procession. During the Velankanni festival, there are ratha yatras everyday. Three chariots are taken out every day with Mary, St. Anthony, and St. Michael; on the penultimate day there are six chariots and on the last day, seven. Common to some other large churches, as Joanne Waghorne has shown, they are also distinctive from the Hindu ones in many minor details. (Waghorne: 25) Waghorne, in her study of the chariot festival at Avur, also shows how these festivities and rituals are acceptable to the institutional Catholic hierarchy. This happens when the festivities pose no threat to the institution; if their lineage is ecclesiastic; and if one can place "the history of the festival within a strict Church genealogy" (Waghorne 2002: 18)

It is not just the vision of Mary that is venerated in Velankanni, but in the perception of many devotees, the land itself is holy. So popular is the church in Velankanni that it has now spawned a few "branches." The Velankanni shrine in Chennai / Madras was built in 1972 by Rev. P.T. Arulappa. This shrine too, like the one near Nagapattinam further south, is on the shores of the Bay of Bengal. While inaugurating it, the then chief minister of Tamilnadu is supposed to have said that one should worship in the Chennai shrine before one went to the one near Nagapattinam.

The Chennai shrine for the Mother of Health and Healing in Besantnagar is located close to a famous Hindu temple-also relatively new-in the area. This is the temple to the Goddess Lakshmi. Within a short distance, therefore, we have two powerful female deities. Hindu devotees go to one or both; Christian devotees, of course, go only to one. In recent years, Velankanni has also been installed at the Basilica of the National Shrine of the Immaculate Conception in
Washington DC. The oratory was dedicated on August 15, 1997, a day after India's celebration of 50 years of independence from the British. The golden statue of Arogya Mata, the Mother of Health, an identical replica of the original, had been consecrated earlier on May 30, 1997 in Velankanni, India and brought to the United States. While the oratory was a gift of the Indian American Catholic Association in Washington, D.C., Tamil-speaking Hindus also contributed to this event.

\section{Lourdes of the East: A Place in the Tamil, Indian, Roman Catholic, and Trading Maps}

Velankanni is not just local and Tamil although its appeal is largely to Tamilspeaking pilgrims. The clergy there speak of the shrine in national and international terms. Prayers are said to be offered in all Indian languages and on behalf of people of all religions. (However, most of the services are in English, Tamil, or Malayalam, with other south Indian languages being used during the festivals). Given the diversity of the Indian population, anything that flows in the direction of creating harmony or unity is seen as good. Internet sites articulate what is reiterated on the ground over and over again; the representation of many languages and many religions is said to make " the shrine a symbol of communal amity and national integration." (Internet site \#2)

It is not just a claim for national integration; Velankanni also maintains an integral connection with both the Roman Catholic and the western world, on the one hand, and the "Far East" on the other. "To the 'Far-East,' the Shrine at Vailankanni is the replica of Lourdes" says Rev. Gabriel, and, in fact, he subtitles his book "Lourdes of the East." Later, he reiterates this point:

Even to the people of the far-east, Vailankanni is 'Holy-land' and it becomes a long cherished goal that they should one day or the other 
step into this Shrine during their life time. (Gabriel et al. 3)

But it is not just sacred for the people of the "Far East." Velankanni seems to be at the crossroads of the east and the west, the liminal land in the maps. For Catholic pilgrims, Velankanni is connected with other sites of Marian apparitions-Lourdes, Fatima, etc. (Gabriel et al. 4) Pope John Paul II is said to have referred to it as "the Lourdes of the Orient" on July 4, 1988. (quoted in Samy 37) More important, just its timeless sacrality is reiterated; the official website of the Velankanni church highlights its ancient, historical, trade connections with Rome:

Our Lady of Vailankanni devotions down through the centuries have proved the Shrine to be of divine origin and has assumed international character. Mary, the focus of unity at Vailankanni, is a clear proof of international, multicultural, and religious harmony.....Readers may be startled to learn that Vailankanni was once a port and there is evidence to prove this. Historical notes reveal that people in this area traded with Rome and Greece, the ancient commercial centers of the western world. In the course of time, Nagapattinam expanded and this tiny . commercial center (Vailankanni) gradually lost its importance. (Internet Site \# 1; italics added; repeated largely from Gabriel et al.: 2)

Hearing this, we have a sense that this is not just an accidental site for the Marian appearance. This site was long connected with Rome; it was always meant to be. One may note in passing that similar claims are made in the Nagore dargah: Shahul Hamid is connected with different parts of India, makes pilgrimages to the middle-east, is spiritually connected with al-Jilani and the
Qadariya order, but lives and is physically interred in Nagore.

These connections and the power of the place lead one to a simple conclusion: "Vailankanni is the most important destination and almost the synthesis of all Marian Sanctuaries for the pilgrims of the world" (Internet site \#1).

The shrine for Infant Jesus is much newer and self-consciously modeled on the one in Prague. While the church is very popular, articulations of the intrinsic sacrality of the land are just beginning to emerge as in the songs quoted earlier. The books also say that the shrine is built on land that was originally a rose garden. Roses, of course, are sacred to Mary.

The two churches are very different in their location. Velankanni, although close to the town of Nagapattinam, is still off the beaten path for most Indians. It is also known primarily by word of mouth, and, although there are pilgrims from many places, most are of Tamil origin. Its location on the shores of the Bay of Bengal helpsmost promoters make it as part of a package tour in south India. The shrine of the Infant Jesus, however, is very urban, very centrally located in a large, booming city. Bangalore has grown extensively with telecommunication companies. The people who come regularly to this shrine are largely locals who live in the city which has, in addition to its Kannada-speaking citizens, a sizeable Tamil population. When people go to Velankanni, it is frequently a pilgrimage or one combined with a vacation tour; when people go to Infant Jesus, it is because they are there in the vicinity of this powerful shrine.

And how do the Hindu pilgrims perceive these places? Obviously, there are many viewpoints, and perhaps as many reasons as the number of Hindus who come here. But some patterns are discernible and emerge when one speaks to the pilgrims. I have spoken extensively with family, friends, acquaintances, as well as random 
pilgrims, and there are some remarkable similarities in their answers.

Most Hindus go to Velankanni or Infant Jesus for the same reasons they may go to a dargah. They do not go to all Christian churches and certainly not to mosques to pray-they go to particular sites of the "other" religions where there is said to be "power." Hindu pilgrims tend to call it "shakti;" Muslims call it "barakat." This power is perceived to be in the presence they feel in the holy place; in the narratives of miracles; the ritual of being in the same place and same time with others who share in this hope. They go with petitions or for thanksgiving, or because it has become the tradition in their family to go there.

How then do the Hindu pilgrims perceive these shrines? As places of power, like the many sacred places in Hinduism. Is the deity absolute? One may get many answers for this question but devotees think of the Mother of Health and the child-God to be sources of power and compassion. This is one more revelation of power, one in which they can participate with the right rituals. And the right rituals turn out to be Hindu, local community ones-rolling on the ground, offering silver etchings of one's body parts, bathing in the sea. The "elite," the priests, participate and encourage this "popular" religion which they articulate as "Indian" and "Tamil."

But the power, the participation in Christian venues, is sharply limited for the millions of pilgrims. The power is here, in Velankanni, or in Infant Jesus, or in any one of the many specific shrines dotted all over south India-St Anthony's church in Madras, Arokia-marianmma in the Shrine Basilica of Our Lady of Health in Shivajinagar, Bangalore, Sister Alphonse's chapel in Greenways Road in Madras, and so on. These are preferred pilgrimage spots; Hindus do not frequent all churches or shrines. They do not, for instance, go regularly to Sunday mass at the neighborhood church or frequent local mosques. Only some places are deemed as sacred spots, some places have divine beings who, though they are beyond such earthly desires, are merciful and powerful enough to help those of us who are still caught in this worldly web. Divinity is both generic and specific. Generic enough to appear in many places, but forceful, powerful because it is local, it is in the form of Arogya Mata or Infant Jesus. And they recognize that power as being that of Mary or the Infant Jesus; it is not Parvati, Durga, or baby Krishna. In other words, it is not a simple "mushiness" of confusing religions and rituals. People who come here may have never heard of the "One Truth, many paths" dictum that many urban educated Hindus articulate. They recognize that the paths are distinctive, though perhaps similar.

Despite the format of the rituals, when they visit Velankanni or the Shrine of the Infant Jesus, Hindus know they are not in yet another temple. They recognize that this is a Christian place of worship; the Velankanni shrine is near the Mahalakshmi temple in Besantnagar and, certainly, Hindus know the difference between the two. But they also believe that in some spaces, the spiritual power that their friends or neighbors testify to transcends institutional identification and categories.

And do they think of themselves as betraying their faith when they go to these temples? The answer here is not so much a "yes" or a "no;" it may be more accurate to say that this is not a relevant question for many Hindus, especially when they do not think of Velankanni or Infant Jesus in terms of institutional affiliation or control. For many Hindu communities-though there are many notable exceptions-pluralism extends beyond social orientations and reality; it is theological. It is perhaps this feature that distinguishes many Hindus from their Christian neighbors who may live and participate in a diverse, pluralistic society, but theologically be connected to a certain deity exclusively. Christians, after all, ordinarily do not go to Hindu temples. There are several notable exceptions here, 
but that seems to be the general rule, at least in the perception of Hindus.

Thus, Hindus acknowledge that they most often go to Hindu temples, but on occasion (or for some people, regularly), they frequent dargahs or specific Christian churches for time-sensitive reasons. This is, perhaps, yet another expression of the wide, capacious tent they loosely understand as their faith. In matters of requesting favors, they feel comfortable going to alternative venues. Almost no Hindu is here in the church to plead for moksha; but for that matter, most of the younger devotees do not think of moksha even in the Hindu temple. And it would be somewhat unlikely that even an elderly Hindu who goes to these shrines thinks of Arogya Mata or the Infant Jesus as the person who gives them moksha. However ephemeral or tenuous this line, it is perhaps this that marks the boundaries between who passes as a Hindu and who as a Christian in this particular context. In other contexts, of course, the lines are much sharper. And most certainly, the lines are very clear when it comes to who one's daughter or son should get married to and who gets to conduct rituals of birth, weddings, or death.

\section{Custom Narrative and Practices: Borderlands and Fuzzy Ground}

The rituals performed in the church or the dargah are local ones practiced by various Hindu communities in South India. The world views, beliefs, practices, and traditions of Hindus are not just based on the written texts. While arguably there are many deeply moving and philosophically sophisticated texts in the Hindu tradition, the enduring experiences that most Hindus have of their traditions come through what one may call "custom" narratives and practices that are deeply connected with their embodied cosmologies. The term "custom" is used primarily as an adjective but also as a noun; it refers to received narratives and practices that are all customary, that is, part of tradition, and customized; Hindus of every stripe are actively engaged in choosing and adapting stories and practices, both "within" and "without" their traditions, customizing them, making them relevant. The words "within" and "without" cannot be precise; as we have noted several times in this short essay, borderlands are fuzzy ground. What we have not elaborated on is how these issues are also getting to be contested territory.

The customary practice may belong to one's sub-group, or larger group, or may be "borrowed" and adapted from other sources Hindus encounter and embody these narratives and practices through their relationships, both synchronic and diachronic, with families, communities, nature, and deities. Thus, although there may be many texts of ayurvedic healing, most Hindus who know them would have learned of them through a grandmother, a neighbor, or a friend. Pilgrimages to Velankanni or visits to the Infant Jesus Shrine also begin this way. And when one goes here, one carries a garland, fruits, flowers, bathes in the sea, rolls on the ground, offers silver pratimas or, when so instructed, do nine-hour novenas.

\section{Shared Ritual Space, Contested Territory}

It is not just Hindus who carry out their own rituals at these shrines. As we saw earlier, the church rituals may include forms of Hindu religiosity such, as the chariot festivals, raising and lowering of the (temple/ church's) ritual flag to mark the beginning and concluding events of a festival and so on. For a while there had been a strict watch over such issues of accommodation by the Catholic church, but since the mid twentieth century, such accommodation and inculturation is not just accepted, it is encouraged. The music, processions, etc. are familiar ways of expressing piety in Tamilnadu. Hindu pilgrims identify with the music and the 
processions. The lyrics and "code" words are familiar, the tune catchy. The chariots pulling the deities and saints are common in many places-is it possible that an unsuspecting Hindu may think of these as expressions of just another Hindu community? And is such an impression meant to be deliberate?

Christians here think of Tamil as their native language, their mother tongue-this is the way in which they express their piety. From the viewpoint of many Tamil Christians, many of the traditional rituals are not accomodation at all. They consider the customs as part of the ethnic heritage; shaving the head, for instance, is also done by Tamil Muslims in dargahs. They think of the Tamil customs as their heritage and do not believe there is any "accommodation." On the other hand, there is a political dimension to this inculturation.

In many parts of India, however, "Hindu" or "local" customs are now being used to present the messages of the Bible. Thus, forms of the performing arts familiar in India-music, dance, etc., can be deployed to spread the teachings of the gospel. What do we make of vegetarian kitchens, saffron saris for nuns, sannyasi robes for priests, straw mats for meditation, yoga, Sanskrit epithets, or calling Jesus or God the Father as Sat chit ananda? Many Indian Christians think of this as a spontaneous expression of their faith. In post-colonial India, people have just begun to come out of the cultural colonization and explore and be comfortable with their own local and national cultures. This has coincided with accelerated globalization and modernization. Politicians and Hindu activists, and now many Hindus across the spectrum believe that by presenting Christianity in "Hindu" (they do not think of this as "Tamil" or "ethnic") forms and media, they are misleading the unsuspecting pilgrim or devotee. To a large extent, this would not be relevant in urban centers such as Bangalore, where the devotee can be quite sophisticated. The problem prima facie seems to be a "no-win" situation. If the Church maintains a "foreign" culture, they are considered to be an alien religion; if they adopt local customs, they may be accused of using local forms for conversion purposes.

Most Hindus devotees do not worry about local ways of worship seen in Velankanni when they are there. However, a rising anger is seen in another context-the perception of the aggressive strategies adopted by the many Christian. churches in the process of evangelization. And one of the main ways in which this program is carried out is through inculturation. Let us take, for instance, a statement issued by the Consultation on Evangelization and Inculturation organized by the Federation of Asian Bishops Conference in March 2000, in Bangalore, India. They said that "Since the Church in Asia is a community on mission, evangelization is its central task. It enters into every aspect of human life. Inculturation is an inseparable element of evangelization." (Internet site \# 3) It further suggested that there should be a consultive team of experts to plan the activities and that "a core group be formed to prepare a seminar kit on inculturation, to be made use of by the local Churches for their animation work." The statement called for greater use of media resources. for promotion of people's cultures. The primary message that came through was reiterated in suggestion number 4 of this document: 'Since evangelization is the central task of the Asian Churches and therefore of all the Offices of the $\mathrm{FABC}$, we recommend that the dimension of inculturation be present in the activities of all other Offices of the FABC." (Internet site \# 3)

It is this programmatic way of picking and choosing local culture to help in the spread of Christianity that upsets many Hindus. Again, it is context-specific-during the pilgrimage and while hearing their friends speak about their faith, the familiar practices seem to fit in with the milieu and also articulate the Hindu devotee's faith. When one pulls back and considers this as 
part of a larger strategy, as something constructed, their displeasure and hostility increases. At issue is this: are the local practices, rituals, and symbols so integrally embedded within the larger Hindu culture to be taken out of their context, used to articulate the Christian faith, as a way of attracting new converts, and thus be turned against Hindu traditions themselves? It is not the issue of inculturation, then, which is the problem, it is its linking with conversion issues. These issues are also associated with perceived grievances; for instance, say many Hindus, the central government which does not think twice about walking in and managing Hindu temples and revenues will not dare to tread on the sacred ground of minority territory.

Fifty years ago, inculturation was not even an issue. There were still restrictions within the church on how far accommodation could go and India was also still in the early years of post-colonial rule. Ironically, under colonial rule, Christianity remained by and large a foreign religion. Ironically too, a Christianity that is in the process of Indianization may even fit into certain notions of how one may be a "Hindu"-geographically and culturally-but in the process, sweep the rug from under the Hindu's feet. Many of these perceptions are layered simultaneously in a new era of heightened political consciousness. Meanwhile, thousands of Hindus throng at the ports of power at Velankanni and the Infant Jesus Shrine, praying, worshiping, pleading, glorifying, and fulfilling vows. It is through framing and reframing concepts and practices in ways that one is familiar with that we continuously create and change the bricolage of our religious imagination. Sacred land, common ground, shared ritual space, contested territory.

\section{Sources}

Gabriel, Rev. Fr. 1995. (Along with S.L., I Arokiasamy, P Xavier, D. Amudhan, A. Philomin Raj and S.
Kulandainathan.) The History of the Shrine Basilica of Our Lady of Health Vailankanni (The Lourdes of the East). Veilankanni: Published by the Church.

Hall, David D. 1997. Ed. Lived Religion in America. Princeton: Princeton University Press.

Irudayam, Very Rev. Fr. G. Arul and K. Maria Pankiras. 2002. The History of the Shrine Basilica of our Lady of Health, Vailankanni (the Lourdes of the East). Shrine Basilica, Vailankanni: Bishop Gabriel Publication. (An Updated Version of Rev. Gabriel's work)

Kulandai iyesuvin jepach chendu. 1997. (Meditative collection on the Infant Jesus). Tamil Publication, no author, Viveknagar, Bangalore, 560 047: Infant Jesus Shrine.

Orsi, Robert. 1997. "Everyday Miracles: The Study of Lived Religion." in David Hall, ed. Lived Religion in America. Princeton: Prịceton University Press, 3-21.

Raj, Selva J. and Corinne C. Dempsey. 2002. Popular Christianity in India: Riting between the Lines. Albany, NY: State University of New York Press.

Samy, R.K. Fr. 2002. Veilankanni: The Earthly Sion. Veilankanni: Published by the Rector and Parish Priest.

Waghorne, Joanne Punzo. "Chariots of the God/s: Riding the Line Between Hindu and Christian in South India" in Popular Christianity in India: Riting Between the Lines, Corrine Dempsey and Selva Raj, 
32 Vasudha Narayanan

eds. SUNY Press, 2002, 11-37.

Internet site \# 1:

http://www.vailankannichurch.org/a

bout-vailankanni.htm

Internet site $\# 2$ :

http://www.9nholidays.com/velanka nni/ourlady.htm

Internet site \# 3:

http://www. fabc.org/oe/evan incul. $\underline{\mathrm{htm}}$

Arputa kulantai iyesu. Viveknagar, Bangalore-47: Infant Jesus Shrine. Madras: Lauvi Productions

Vanden un tirupadam. Viveknagar, Bangalore 560. 047: Infant Jesus Shrine

Miraculous Infant . Jesus. Viveknagar, Bangalore 560 047: Infant Jesus Shrine

Audio Cassettes: 